\title{
Analysis of Horizontal Well Operation at the Zhanazhol Deposit
}

\author{
Nurlan Aldamzharov ${ }^{*}$, Samal Akhmetzhan², Larisa Churikova ${ }^{3}$, Yermek Aitaliyev ${ }^{4}$, \\ Gali Gumarov ${ }^{4}$, Raman Mameshov ${ }^{2}$, Yerkessulu Konasheva ${ }^{3}$ \\ 1 LLP “Technopark Zerek", Aktobe, Brothers Zhubanovy Str., 302/a, Republic of Kazakhstan \\ 2 Kazakhstan University of Innovative and Telecommunication Systems, Uralsk, Republic of Kazakhstan \\ 3 West Kazakhstan Agrarian Technical University, Uralsk, Republic of Kazakhstan \\ 4 West Kazakhstan State University, Uralsk, Republic of Kazakhstan \\ * Corresponding author's e-mail: aldamzharov.nurlan@mail.ru
}

\begin{abstract}
The need for accelerated economic growth sets the task of increasing efficiency and improving the quality of drilling for the oil industry. This task includes both quantitative growth, i.e. an increase in the speed of drilling, and improvement of the quality of drilling operations themselves. One of the most important factors of quality improvement is the drilling of directional and, particularly, horizontal wells strictly according to the project. This paper provides a brief analysis of the operation of horizontal wells at the Zhanazhol deposit. It also presents studies on the statistics of the effective length of horizontal well sections.
\end{abstract}

Keywords: bottomhole, section drilling, directional wells, oil and gas industry

\section{INTRODUCTION}

This paper analyzes technical and technological solutions for the operation of horizontal wells as well as the feasibility and efficiency of construction of multilateral wells, taking into account the development prospects of this area (Oganov et al., 2001).

In order to avoid undesirable consequences of well inclination, it is necessary to know the causes and patterns of inclination as well as to ensure the construction of wells in the intended direction. The knowledge of inclination laws is also important for the implementation of whipstocking. It makes it possible to avoid the location of wells with inclined holes and to intersect the reservoir at several points from one main hole.

The main principles of drilling of directional and horizontal wells served as the basis for the development of the method of reservoir multihole opening, providing a multiply expanded drainage zone and a surface of filtration in the reservoir. This method is also used for drilling additional holes to extend the life of the production well. The use of multihole drilling and the creation of holes in an already drilled well is a modern trend in directional drilling technology.

In 1928 E.A. Spenser received a patent for a tool for cutting a multitude of "slots" in the casing string using a whipstock. In 1931 D. Dana registered a patent for a bottomhole device that allowed selecting three separate directions for drilling a bore hole. In 1939 L. Ranney drilled the first horizontal well. He also stated that he drilled more than one horizontal hole, i.e. created a multihole well (Grigoryan, 1969). However, it was not until 1953 that A.M. Grigoryan in cooperation with Yu.P. Borisov considered some of the main theoretical issues of construction of multihole wells (Grigoryan, 1969).

The above-mentioned researchers defined a multihole well as a complex object of industrial construction. They described the main characteristics of oil deposits, in which there is a need and expediency to build multihole wells, as well as distinguished the types of profiles of these wells 
for different geological and technical conditions and characteristics of reservoirs. The fundamentals of the domestic drilling technology for horizontal wells in Kazakhstan were laid in the 2000s. The analysis of the operation of horizontal wells shows that the creation of multihole wells and a multilateral horizontal well, as a special case, is one of the ways to increase the oil recovery of low-productive reservoirs and deposits in remote areas of the shelf and nature protection zones (Grigoryan, 1998).

Currently, a methodology has been developed for calculating the design profiles of horizontal wells of various types. These include profiles with a straight horizontal section in the reservoir, profiles with a low-intensity set and a decrease in the zenith angle in the reservoir, and profiles with a sinusoidal section of the hole in the reservoir. The methodological basis for calculating such profiles and designing multihole wells that would cover the entire diversity of mining-geological and operational conditions has not yet been developed. One of the most important tasks is also to create a computerized spatial model and software for the design and management of multihole wells (MHW).

The purpose of the study is to substantiate and improve technological methods for drilling deep directional horizontal wells (DHW) and horizontal wells (HW) as well as to prevent negative deviation in drilling, ensuring a significant increase in drilling performance and its quality.

The relevance of the work is to establish the following, using numerical methods of problem solution based on the geological and mathematical fragments of the deposit:

1) Effect of the length, location and combination of the lengths of horizontal holes on the development indices of fragments of homogeneous and inhomogeneous deposits of massive and reservoir types, drilled DHW, HW and MHW;

2) Effect of the completion of DHW, HW and MHW on the productivity of the well and the reduction of contamination of the bottomhole part of the reservoir from the drilling mud;

3) Improvement of technological methods for drilling deep directional and horizontal wells (Aldamzharov, 2003);

The main research tasks are as follows:

1) To analyze and compare existing analytical methods for the construction and operation of directional horizontal wells in the de- posits of the Republic of Kazakhstan and the CIS countries;

2) To study the effect of the length, location along the depth of the deposit and combination of the lengths of horizontal holes on the development indices of fragments of homogeneous and inhomogeneous deposits of massive and reservoir types, drilled DHW, HW and MHW;

3) To use the developed method of the qualitative forecasting of zenith inclination for solving specific problems in the construction of directional horizontal oil and gas wells.

\section{METHODS}

A set of the following research methods were applied in the study:

- analysis of the drilling experience of horizontal wells at the Zhanazhol deposit (Republic of Kazakhstan);

- use of theoretical foundations for the construction of oil and gas deposits by the system of directional and horizontal wells;

- mathematical experiments on the constructed geological and mathematical models of fragments of homogeneous and inhomogeneous deposits of massive and reservoir types.

\section{RESULTS}

2407, 2444 and 2127 are the first horizontal wells located in the western part of the reservoir units $\mathrm{G}_{\text {north }}$ and $\mathrm{D}_{\text {south }}$. The depths along the holes are $4,029 \mathrm{~m}, 3,950 \mathrm{~m}$ and 4,080 m, respectively. The lengths of horizontal holes are $251 \mathrm{~m}, 131 \mathrm{~m}$ and $367 \mathrm{~m}$, respectively (Aldamzharov, 2001; 2003).

\section{Drilling of oil-saturated reservoirs}

According to the downhole survey, the overall area of reservoirs drilled by the well 2407 (in the intervals of $3,649-4,022 \mathrm{~m}$ ) is $373 \mathrm{~m}$. The capacity along the hole is $223.4 \mathrm{~m}(43.3 \mathrm{~m}$ - vertically). The geophysical parameters of this and neighboring wells are presented in Table 1 . The well is drilled in reservoirs having a relatively positive geophysical property (Zainullin, 1995). A comparison of the data of the well 2407 and the neighboring wells 2413, 2406, 2402 shows that all the overlying oil-saturated reservoirs have been completely drilled by the well 2407 . 


\section{Characteristics of oil production}

Well 2407. When comparing the current state of the well 2407 and the wells 2413, 2406, one can see the following common characteristics: - the reservoir pressure is lowered (initial reservoir pressure is $39 \mathrm{MPa}$, final pressure 24.6-26.3 MPa); - they operate on the basis of the free-flow production method (except for the well 2413) - gas lift oil extraction (Aliyev et al., 2001).

It is possible to analyze three wells in terms of oil production. When comparing the indices of oil production of the well 2407 with the neighboring wells 2413 and 2402, one can note that cumulative oil production is 1.26 times more than that of the well 2402 and 3.07 times more than that of the well 2413 . The average daily oil flow rate is 1.3 and 2.85 times more, respectively (Table 2 ).
Well 2444. The average daily oil flow rate of the well 2444 is 1.11 times more than that of the well 2442 (Table 3).

Well 2127. The initial average daily oil flow rate of the well 2127 is 1.25 and 1.56 times more than that of the wells 2120 and 2119 , respectively. The oil production figures for the well 2127 are slightly higher than those for the neighboring wells (Table 4).

At the beginning, a high average daily oil flow rate was obtained, but it gradually decreased. The initial average daily oil flow rate (with the approximate size of the choke) is, respectively, 1.33 and 1.8 times more than that of the wells 2402 and 2413. However, the average daily oil flow rate is gradually decreasing. At the beginning of the well commissioning, a high average daily oil flow rate, compared to the neighboring wells, was obtained,

Table 1. Geophysical properties of the well 2407 and neighboring wells

\begin{tabular}{|c|c|c|c|c|c|c|c|c|}
\hline \multirow{2}{*}{ Well } & \multicolumn{2}{|c|}{ Oil-saturated thickness, $\mathrm{m}$} & \multicolumn{2}{|c|}{ Porosity, \% } & \multicolumn{2}{|c|}{ Oil saturation, \% } & \multicolumn{2}{|c|}{ Permeability, $10^{-3} \mu \mathrm{m}^{2}$} \\
\hline & along hole & vertically & $\min$. & $\max$. & $\min$. & $\max$ & $\min$. & $\max$. \\
\hline 2407 & 223.4 & 43.3 & \multicolumn{6}{|c|}{$\mathrm{n} / \mathrm{a}$} \\
\hline 2413 & & 43.6 & 8.45 & 9.98 & 69.61 & 76.97 & 0.22 & 1.09 \\
\hline 2406 & & 31.6 & 10.86 & 11.64 & 59.27 & 64.32 & 2.71 & 6.09 \\
\hline 2402 & & 45.4 & 8.69 & 10.64 & 66.82 & 79.77 & 0.28 & 2.16 \\
\hline 2444 & 85.2 & 24.25 & 9.59 & 10.28 & & & 0.72 & 1.48 \\
\hline 2442 & & 44.8 & 9.6 & 10.24 & 72.86 & 72.86 & 0.73 & 1.42 \\
\hline 2449 & & 60.7 & 11.34 & 12.86 & 71.8 & 71.8 & 4.46 & 21.62 \\
\hline 2437 & & 27.8 & 10.68 & 10.68 & 80.56 & 80.56 & 2.25 & 2.25 \\
\hline 2127 & 307 & 58.32 & 7.42 & 8.9 & 79.44 & 83.28 & 0.076 & 0.354 \\
\hline 2120 & & 57.7 & 8.11 & 8.92 & 68.16 & 81.52 & 0.156 & 0.361 \\
\hline 2134 & & 29.7 & 7.83 & 9.41 & 68.10 & 81.37 & 0.117 & 0.601 \\
\hline 2119 & & 40.5 & 9.62 & 9.80 & 71.86 & 72.81 & 0.748 & 0.901 \\
\hline 2135 & & 50.4 & 7.70 & 8.64 & 73.35 & 78.84 & 0.102 & 0.270 \\
\hline 2004 & & 49.9 & 8.45 & 8.67 & 69.46 & 71.65 & 0.222 & 0.279 \\
\hline
\end{tabular}

Note: All geophysical parameters presented are average weighted.

Table 2. Comparison of the oil flow rate of the well 2407 with the neighboring wells 2413 and 2402

\begin{tabular}{|l|l|c|c|c|}
\hline \multicolumn{2}{|c|}{ Well } & 2407 & 2413 & 2402 \\
\hline \multirow{4}{*}{$\begin{array}{l}\text { Average daily oil flow } \\
\text { rate, tons per day }\end{array}$} & Initial & $120(9 \mathrm{~mm}$ choke $)$ & $65(9 \mathrm{~mm}$ choke $)$ & $90(9 \mathrm{~mm}$ choke $)$ \\
\cline { 2 - 5 } & From development to September 2013 & & 38.65 & 75.25 \\
\cline { 2 - 5 } & September 2013 - January 2015 & 79.13 & 27.69 & 60.85 \\
\cline { 2 - 5 } & January 2015 & $52(7 \mathrm{~mm}$ choke $)$ & $75(9 \mathrm{~mm}$ choke $)$ & $48(7 \mathrm{~mm}$ choke $)$ \\
\hline
\end{tabular}

Table 3. Comparison of the oil flow rate of the well 2444 with the neighboring wells 2442 and 2449

\begin{tabular}{|l|l|c|c|c|}
\hline \multicolumn{2}{|l|}{ Well } & 2444 & 2442 & 2449 \\
\hline \multirow{2}{*}{$\begin{array}{l}\text { Average daily oil flow rate, } \\
\text { tons per day }\end{array}$} & Initial & $86(7 \mathrm{~mm}$ choke $)$ & $45(6 \mathrm{~mm}$ choke $)$ & $70(7 \mathrm{~mm}$ choke $)$ \\
\cline { 2 - 5 } & From development to January 2013 & & 34.4 & \\
\cline { 2 - 5 } & February 2013 - January 2015 & 64.80 & 20.94 & 78.13 \\
\hline
\end{tabular}


Table 4. Comparison of the oil flow rate of the well 2127 with the neighboring wells 2120 and 2119

\begin{tabular}{|l|l|c|c|c|}
\hline \multicolumn{1}{|c|}{ Well } & 2127 & 2120 & 2119 \\
\hline \multirow{3}{*}{$\begin{array}{l}\text { Average daily oil flow rate, } \\
\text { tons per day }\end{array}$} & Initial & 12.5 & 10 & 8 \\
\cline { 2 - 5 } & From development to November 2013 & & 8.9 & 6.5 \\
\cline { 2 - 5 } & November 2013 - January 2015 & 14 & 8 & 5.6 \\
\hline
\end{tabular}

but it gradually stabilized at a level of 60 tons per day (Oganov et al., 1999; Oganov 1999).

The initial average daily oil flow rate with a $7-\mathrm{mm}$ choke is 86 tons per day, while in the neighboring well 2449 this figure is 70 tons per day. Although the average daily oil flow rate is 1.22 times more than that of the well 2449, it falls sharply. The average daily oil flow rate grew at the beginning of the well commissioning, but then decreased. For the period from December 2013 to October 2015, in 11 months only with a constant choke the average daily oil flow rate decreased from 95 tons per day to 66 tons per day. The decline rate of oil production here is $30 \%$. The average daily flow rate from the neighboring well 2442 from January 2013 to January
2015 decreased from 47.23 tons to 19 tons. The decline rate of oil production is $20 \%$, which is $10 \%$ less than in the well 2442 .

Under a large pressure drawdown, the well productivity index is low. The statistical results of changing the well productivity index are presented in Table 5. The pressure drop is comparable to the well 2449 , but the well 2444 has a lower productivity index than the well 2449 .

Under a low pressure drawdown, the well productivity index is high. The results of changing the well productivity index are presented in Table 5. Compared to the neighboring wells, the pressure drop of the well 2407 is less, the productivity index is high, sharply reduced, and then stabilized (Figure 1).

Table 5. Results of changes in the well productivity index

\begin{tabular}{|c|c|c|c|c|c|c|c|}
\hline Well & $\begin{array}{c}\text { Date } \\
\text { (year, month) }\end{array}$ & $\begin{array}{c}\text { Choke, } \\
\mathrm{mm}\end{array}$ & $\begin{array}{c}\text { Average daily oil } \\
\text { flow rate, tons per } \\
\text { day }\end{array}$ & $\begin{array}{c}\text { Reservoir } \\
\text { pressure, } \\
\mathrm{MPa}\end{array}$ & $\begin{array}{c}\text { Bottomhole } \\
\text { pressure, MPa }\end{array}$ & $\begin{array}{l}\text { Pressure } \\
\text { drop, MPa }\end{array}$ & $\begin{array}{c}\text { Well productivity } \\
\text { index, tons per } \\
\text { day }\end{array}$ \\
\hline \multirow{6}{*}{2413} & 1992.09 & 5 & 40 & 39.7 & 34.8 & 4.9 & 8.16 \\
\hline & 1997.09 & 5 & 20 & 27.5 & 23.5 & 4 & 5.00 \\
\hline & 1998.01 & 7 & 20 & 26.8 & 18.1 & 8.7 & 2.30 \\
\hline & 2000.01 & 3 & 12 & 26.3 & 22.2 & 4.1 & 2.93 \\
\hline & 2009.08 & 8 & 25 & 25.8 & 16.7 & 9.1 & 2.75 \\
\hline & 2013.01 & 7 & 51 & & & & \\
\hline \multirow{6}{*}{2402} & 1990.3 & 5 & 50 & 40.8 & 38.3 & 2.5 & 20.00 \\
\hline & 1997.09 & 9 & 75 & 30.7 & 25.8 & 4.9 & 15.31 \\
\hline & 1998.01 & 9 & 75 & 24.5 & 21.1 & 3.4 & 22.06 \\
\hline & 2000.01 & 7 & 55 & 24.5 & 19.2 & 5.3 & 10.38 \\
\hline & 2009.08 & 9 & 52 & 22.6 & 19.1 & 3.5 & 14.86 \\
\hline & 2013.01 & 7 & 48 & 21.2 & 19.5 & 1.7 & 28.24 \\
\hline \multirow{7}{*}{2407} & 1997.09 & 9 & 150 & 25.2 & 24.5 & 0.7 & 214.29 \\
\hline & 1998.01 & 9 & 105 & 25.2 & 24.5 & 0.7 & 150.00 \\
\hline & 1998.06 & 15 & 150 & 25.2 & 17.4 & 7.8 & 19.23 \\
\hline & 2000.01 & 5 & 19 & 20.8 & 19.5 & 1.3 & 14.62 \\
\hline & 2009.08 & 7 & 30 & 20.8 & 19.2 & 1.6 & 18.75 \\
\hline & 2013.01 & 7 & 26 & 21.8 & 20.4 & 1.4 & 18.57 \\
\hline & 2000.08 & 7 & 45 & 21.8 & 19.7 & 2.1 & 21.43 \\
\hline \multirow{2}{*}{2444} & 2000.10 & 9 & 66 & 24.7 & 16.1 & 8.6 & 7.67 \\
\hline & 2011.01 & 7 & 57 & 24.7 & 19.9 & 4.8 & 11.87 \\
\hline \multirow{2}{*}{2449} & 2000.09 & 7 & 70 & 29.6 & 24.5 & 5.1 & 13.73 \\
\hline & 2015.01 & 9 & 85 & 29.6 & 21.2 & 8.4 & 10.12 \\
\hline 2442 & 2011.05 & 4 & 32 & 35.4 & 30.3 & 5.1 & 6.27 \\
\hline
\end{tabular}




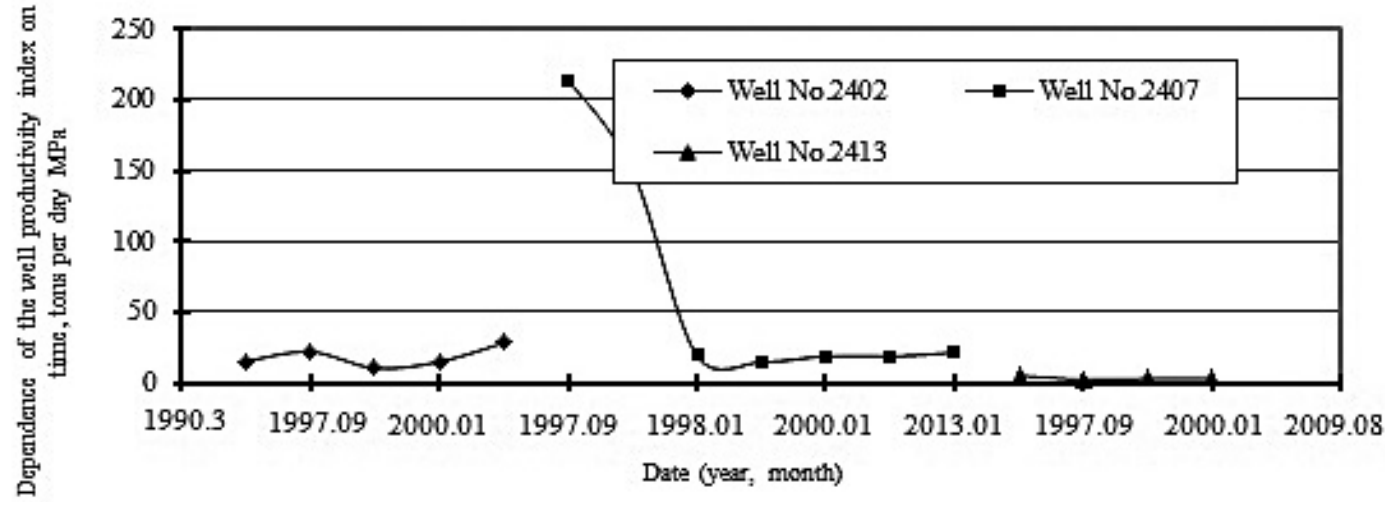

Figure 1. Dependence of the well productivity index on time

\section{DISCUSSION}

Compared to vertical wells, horizontal wells have a high initial average daily oil flow rate. The volume of oil production rapidly decreases. The proper development of impermeable interlayers leads to a decrease in vertical permeability, a lack of energy supply by the gas cap, bottom and extreme water. There is a decline in average daily production to a certain value. Horizontal wells that have opened reservoirs in a small section with increased reservoir pressure operate first with a high flow rate, which rapidly decreases as pressure drops in this section.

The carbonate strata-II $\mathrm{G}_{\text {north }}$ and $\mathrm{D}_{\text {south }}$ are characterized by large intervals of oil reservoirs and numerous oil-saturated interlayers. The low power of one oil-saturated interlayer and the proper development of impermeable interlayers account for the low conductivity of energy and oil supply along the vertical. Based on this, consider the factors that affect the effectiveness of horizontal wells (Basniyev and Aliyev 1999).

1) Large inhomogeneity and unevenness of reservoirs

The study of the profile of reservoirs as well as the degree of their involvement in the development of reserves showed that as the number of perforated intervals grows, there is an increase in the number of intervals that do not give inflows. In operation, due to the strong inhomogeneity of reservoirs, perforated reservoirs with the worst geophysical properties give little or no oil. Similarly, when injected, perforated reservoirs with the worst geophysical properties take little or no water. The productive strata $\mathrm{G}_{\text {north }}$ and $\mathrm{D}_{\text {south }}$ are inhomogeneous in profile (Nikitin el al., 1999).
Table 6 presents the actual results of the well sections (neighboring horizontal wells). It can be seen that the well section is non-uniform. When studying the profiles of the wells 2449 and 2413, it was found out that the porosity of reservoirs varies within $10-13 \%$, and their permeability $-1.11-25 \times 10^{-3} \mu \mathrm{m}^{2}$. The thickness of reservoirs is $17 \mathrm{~m}$ and $15.2 \mathrm{~m}$, respectively. This makes $53.1 \%$ and $57.14 \%$. According to statistical data, the thickness of oil-saturated reservoirs with a porosity of less than $10 \%$ (the well 2444 $-30 \mathrm{~m}$ ) is $35.2 \%$, from all drilled oil-saturated reservoirs. For these reasons, horizontal wells are slightly different from vertical ones. The decrease in production rate is probably due to the drop in pressure of drilling a small part of the reservoir (Technology “TOBUS”, 1997).

\section{2) Large inhomogeneity of oil reservoirs from high} permeable to low permeable reservoir rocks

In the units $\mathrm{G}_{\text {north }}$ and $\mathrm{D}_{\text {south }}$, the maximum thickness of oil reservoirs (from top to base) reaches about $190 \mathrm{~m}$. In one well, perforated oilsaturated reservoirs are more than 7-25 intervals. The average thickness of oil-saturated reservoirs is about $3 \mathrm{~m}$. The reservoir has some intervals of impermeable interlayers (more than 20). The thickness of most impermeable reservoirs varies within 5-10 m. Within a wide range, an impermeable reservoir with a thickness of about $10 \mathrm{~m}$ extends (Churnykh, 1999). This affects power supply to the oil reservoir, resulting in a rapid decline in oil production and reservoir pressure. For example, the average daily oil flow rate with a 15$\mathrm{mm}$ choke is more than 185 tons, but the current oil flow rate with a $7-\mathrm{mm}$ choke is 52 tons (the horizontal well 2407) (Kuliyev, 1986). 
Table 6. Actual results of the well sections

\begin{tabular}{|c|c|c|c|c|c|c|c|c|c|c|c|c|}
\hline \multirow{2}{*}{ Well } & \multicolumn{2}{|c|}{$\begin{array}{c}\text { Perforation } \\
\text { interval }\end{array}$} & \multirow{2}{*}{$\begin{array}{l}\text { Perforation } \\
\text { thickness, } \\
\text { m }\end{array}$} & \multicolumn{2}{|c|}{$\begin{array}{c}\text { Interval of } \\
\text { oil-saturated } \\
\text { reservoirs, } \mathrm{m}\end{array}$} & \multirow{2}{*}{$\begin{array}{l}\text { Effective } \\
\text { oil- } \\
\text { saturated } \\
\text { thickness, } \\
\text { m }\end{array}$} & \multirow{2}{*}{$\begin{array}{c}\text { Average } \\
\text { daily oil } \\
\text { flow rate, } \\
\text { tons per } \\
\text { day }\end{array}$} & \multirow{2}{*}{$\begin{array}{c}\text { Percentage } \\
\text { of oil } \\
\text { production, } \\
\%\end{array}$} & \multicolumn{2}{|c|}{$\begin{array}{c}\text { Porosity, } \\
\%\end{array}$} & \multicolumn{2}{|c|}{$\begin{array}{c}\text { Permeability, } \\
10^{-3} \mu \mathrm{m}^{2}\end{array}$} \\
\hline & from & to & & from & to & & & & $\min$. & $\max$. & $\min$. & max. \\
\hline \multirow{5}{*}{2402} & 3720 & 3726 & 6 & 3720.6 & 3726 & 4.8 & & & 7.8 & 8 & 0.11 & 0.14 \\
\hline & 3731 & 3740 & 9 & 3731.2 & 3740 & 7.4 & 14.4 & 25.83 & 8 & 11 & 0.14 & 3.13 \\
\hline & \multirow{3}{*}{3743} & \multirow{3}{*}{3765} & \multirow{3}{*}{22} & 3743 & 3745 & 2 & \multirow{3}{*}{41.5} & \multirow{3}{*}{74.17} & 6.5 & 7.5 & 0.03 & 0.08 \\
\hline & & & & 3745 & 3752 & 5.4 & & & 10 & 12 & 1.11 & 8.85 \\
\hline & & & & 3753.6 & 3765.6 & 9.8 & & & 8 & 11 & 0.14 & 3.13 \\
\hline \multirow{8}{*}{2413} & 3683 & 3688 & 5 & 3682.6 & 3685.4 & 2.8 & & & 8.5 & 8.5 & 0.23 & 0.23 \\
\hline & 3690 & 3693 & 3 & \multirow{2}{*}{3690} & \multirow{2}{*}{3696.2} & \multirow{2}{*}{4.4} & \multirow{2}{*}{12.6} & \multirow{2}{*}{36.27} & \multirow{2}{*}{9.8} & \multirow{2}{*}{9.8} & \multirow{2}{*}{0.90} & \multirow{2}{*}{0.90} \\
\hline & 3694 & 3696 & 2 & & & & & & & & & \\
\hline & 3698 & 3700 & 2 & 3698.4 & 3700.4 & 2 & & & 10 & 10 & 1.11 & 1.11 \\
\hline & 3704 & 3712 & 8 & 3704.2 & 3712 & 6.4 & 21.4 & 61.66 & 7.5 & 11 & 0.08 & 3.13 \\
\hline & 3714 & 3716 & 2 & 3713.6 & 3716.6 & 2.8 & & & 11 & 11 & 3.13 & 3.13 \\
\hline & 3720 & 3725 & 5 & 3720.2 & 3725.4 & 4.4 & 0.72 & 2.07 & 8 & 10 & 0.14 & 1.11 \\
\hline & 3770 & 3775 & 5 & 3770 & 3775 & 3.8 & & & 7 & 8 & 0.05 & 0.14 \\
\hline \multirow{9}{*}{2449} & \multirow{2}{*}{3591} & \multirow{2}{*}{3606} & \multirow{2}{*}{15} & 3590.8 & 3594 & 3.2 & \multirow{2}{*}{22.4} & \multirow{2}{*}{24.18} & 12 & 12 & 8.85 & 8.85 \\
\hline & & & & 3601.2 & 3606.6 & 3.4 & & & 12.5 & 12.5 & 14.88 & 14.88 \\
\hline & 3609 & 3610 & 1 & & & & & & & & & \\
\hline & 3620 & 3622 & 2 & 3620.3 & 3621.3 & 1 & & & 14 & 14 & 70.63 & 70.63 \\
\hline & 3623 & 3626 & 3 & 3622.8 & 3625.6 & 2.8 & 0.7 & 0.75 & 8.5 & 8.5 & 0.23 & 0.23 \\
\hline & 3644 & 3653 & 9 & 3643 & 3653.4 & 10.4 & 69.7 & 75.07 & 13 & 13 & 25.00 & 25.00 \\
\hline & 3655 & 3661 & 6 & 3654.6 & 3661 & 5 & & & 13.5 & 13.5 & 42.02 & 42.02 \\
\hline & 3666 & 3670 & 4 & 3665.2 & 3669.5 & 4.3 & & & 15 & 15 & 199.5 & 199.5 \\
\hline & 3672 & 3674 & 2 & 3671.6 & 3673.7 & 2.1 & & & 8 & 14 & 0.14 & 70.63 \\
\hline
\end{tabular}

\section{3) Short length of the effective horizontal section}

Experimental work is also carried out on the statistics of the effective length of the well horizontal sections (the horizontal section is understood in this case as a zenith angle of more than $80^{\circ}$ ), and its results are shown in Table 7 . The effective length of the horizontal wells 2127, 2407 and 2444 is $253.6 \mathrm{~m}, 103.8 \mathrm{~m}$ and $55.22 \mathrm{~m}$, respectively (Shamanov, 2001; Eliyashevsky et al., 1982).

It is established that the additional oil production of horizontal wells (as opposed to vertical) is directly proportional to the length of the horizontal section. When comparing the wells 2407 and 2444 with close reservoir properties, one can determine that the effective horizontal section of the well 2407 is longer than that of the well 2444. Therefore, the initial oil flow rate of the well 2407 is higher than that of the well 2444. The reason for the rapid drop in oil production and the receipt of a low volume of additional oil is a small effective length of the horizontal section, which leads to a reduction in the drainage radius (Creation and implementation..., 2000).

Although the length of the effective horizontal section and the drainage radius of the well 2127 are much larger, the porosity $(7.46 \% \sim 8.9 \%)$ and permeability $\left(0.076 \sim 0.354 \times 10^{-3} \mu \mathrm{m}^{2}\right)$ of its reservoirs are lower. However, the additional oil volume here is not high.

4) The method of well completion does not meet the requirements for reservoir development

$\mathrm{G}_{\text {north }}$ and $\mathrm{D}_{\text {south }}$ are classified as inhomogeneous deposits with low permeability. The inho-

Table 7. Actual results of the effective length of horizontal wells

\begin{tabular}{|c|c|c|c|c|c|c|}
\hline Well & Unit & $\begin{array}{c}\text { Interval with a } \\
\text { zenith angle of } \\
\text { more than 80, } \mathrm{m}\end{array}$ & $\begin{array}{c}\text { Length of the } \\
\text { horizontal section, } \\
\mathrm{m}\end{array}$ & $\begin{array}{c}\text { Effective length } \\
\text { of the horizontal } \\
\text { section, } \mathrm{m}\end{array}$ & $\begin{array}{c}\text { Ineffective length } \\
\text { of the horizontal } \\
\text { section, } \mathrm{m}\end{array}$ & $\begin{array}{c}\text { Percentage of the } \\
\text { effective length of the } \\
\text { horizontal section, } \%\end{array}$ \\
\hline 2407 & $\mathrm{G}_{\text {north }}$ & $3802-4020$ & 218 & 103.8 & 114.2 & 47.61 \\
\hline 2444 & $\mathrm{G}_{\text {north }}$ & $3750-3940$ & 190 & 55.2 & 134.8 & 29.05 \\
\hline 2127 & $\mathrm{D}_{\text {south }}$ & $3690-4075$ & 385 & 253.6 & 131.4 & 65.8 \\
\hline
\end{tabular}


mogeneity of oil reservoirs has led to the existence of a large difference in reservoir pressure and properties (Woods and Lubinski, 1960). Drilling wells with the use of high-density mud as well as creating bottomhole pressure that is $3.5 \mathrm{MPa}$ higher than reservoir pressure has resulted in the filtration of clay mud in the oil reservoir with high permeability and accelerated the contamination of the reservoir with clay mud. This is confirmed by the data of the well 2449 , where the porosity of perforated oil intervals is $12 \%-13 \%$, and permeability is $8.85-25 \times 10^{-3} \mu \mathrm{m}^{2}$. However, three perforated intervals with a porosity of $13.5 \%-15 \%$ and a permeability of $42.02-199.5 \times 10^{-3} \mu \mathrm{m}^{2}$ in the base do not give oil inflows. This is explained by the contamination of reservoirs with clay mud. The time of well drilling and flushing with clay mud in the hole of horizontal wells takes a significant place. This leads to the severe contamination of the reservoir, so it is difficult to clean it from clay mud by conventional technology. Currently, the methods of hydrochloric acid treatment and hydraulic fracturing are used for the treatment of oil reservoirs (Oganov et al., 1979; Instruction for directional well drilling, 1966).

Each horizontal well at the Zhanazhol deposit is completed by the method of filter discharge.

\section{Theoretical and practical significance}

The practical value of the study is based on recommendations for the use of DHW, HW and MHW in the construction of oil and gas deposits, taking into account their geological features as well as the impact of technological and technical factors when drilling with directional horizontal, horizontal and multihole wells. These experiments allow choosing such a well drilling technology that provides the maximum profitability of development and the reliable, stable, troublefree work of selected wells. The results obtained in this work can be used in the construction of oil and gas deposits with similar geological and industry characteristics.

\section{CONCLUSIONS}

The complex analysis of horizontal wells allows the following conclusions to be made:

1. Horizontal wells are effective if the reservoir is homogeneous or almost homogeneous in terms of permeability. However, if not homogeneous, the probability of obtaining large flow rates is reduced, but will not be lower than in vertical wells with proper hole drilling.

2. To reduce the effect of inhomogeneous (in terms of impermeability) interlayers, the drilling of multilateral wells is recommended, and to eliminate inactive wells, the method of sidetrack kickoff is advised.

\section{REFERENCES}

1. Aldamzharov N.N. 2001. Construction of horizontal wells at the Zhanazhol deposit. V International Symposium on Drilling Wells in Complicated Conditions, St. Petersburg, 11-15 June 2001, 5-6.

2. Aldamzharov N.N. 2003. Design of the technology of multilateral wells at the Zhanazhol deposit. Oil and Gas Business, Aktobe, pp. 189.

3. Aliyev Z.S. et al. 2001. The rationale and choice of the optimal design of horizontal gas wells. Moscow, pp. 51.

4. Basniyev K.S. and Aliyev Z.S. 1999. Methods for calculating the flow rates of horizontal, directional and multihole gas wells. Moscow.

5. Churnykh V.V. 1999. Evaluation of the productivity of multilateral wells in various sidetracking schemes. Moscow, RSU of Oil and Gas - Neftyanoye Khozyaystvo, 9.

6. Creation and implementation of a multifunctional technological complex for the construction of directional and horizontal holes. 2000. "OAO NPO Drilling Engineering” - VNIIBT. Moscow, pp. 48.

7. Eliyashevsky I.V. et al. 1982. Typical tasks and calculations in drilling. 2nd ed. Moscow, Nedra.

8. Grigoryan A.M. 1969. Reservoir drilling by multihole and horizontal wells. Moscow: Nedra, pp. 123.

9. Grigoryan A.M. 1998. Multilateral wells are the near future of the oil industry. Moscow: Neftyanoye Khozyaystvo, 11, 2-12.

10. Instruction for directional well drilling. 1966. Moscow: VNIIBT, 31, pp. 174.

11. Kuliyev Yu.M. 1986. Improving the technology of directional well drilling by developing and implementing a rational profile of effective bottomhole assembly. Doctoral dissertation. Baku. Azerbaijan State Oil and Industrial University, pp. 165.

12. Nikitin B.A. el al. 1999. Determination of the productivity of horizontal gas wells and reservoir parameters from the results of hydrodynamic studies at stationary modes. Moscow, OAO Gazprom.

13. Oganov A.S. et al. 1999. Current state and prospects for drilling directional and horizontal wells with large hole deviations from the vertical. Moscow, OAO VNIIOENG, pp. 35. 
14. Oganov A.S. et al. 2001. Multihole well drilling: Development, problems and successes. Moscow, OAO VNIIOENG, pp. 4-31.

15. Oganov G.S. 1999. On the issue of choosing the type of wells and the methods of underreaming of the oil and gas deposit. OAO NPO "Drilling Engineering". Moscow, Scientific and Technical Journal, 10, 32 .

16. Oganov S.A. Gasanov I.Z., Kuliyev Yu.M. and Tsybulsky I.S. 1979. Determination of the diameter and length of the stabilizer to ensure conditions to prevent its touching the upper side of hole. Scien- tific works of Azerbaijan State Oil and Industrial University, 3, 21-23.

17. Shamanov S.A. 2001. Drilling and completion of horizontal wells. Moscow, LLC "Nedra Biznestsentr".

18. Technology “TOBUS”. 1997. Moscow.

19. Woods G. and Lubinski A. 1960. Well deviation during drilling. Trans. from English. Moscow: Gostoptekhizdat, pp. 161.

20. Zainullin A.I. 1995. Forecasting of optimal parameters for oil horizontal wells. Moscow, VNIIOENG, Drilling of wells onshore and offshore, 10, 61. 